\title{
$N$-Acetylated Gemini Surfactants: Synthesis, Surface-Active Properties, Antifungal Activity, and Ecotoxicity Bioassays
}

\author{
Laura M. Machuca선 Ulises Reno², Silvana C. Plem¹, Ana María Gagneten², \\ Marcelo C. Murguía1* \\ ${ }^{1}$ Laboratory of Applied Chemistry, Faculty of Biochemistry and Biological Sciences, National University of Litoral, \\ Santa Fe, Argentina \\ ${ }^{2}$ Laboratory of Ecotoxicology, Faculty of Humanities and Sciences, National University of Litoral, Santa Fe, \\ Argentina \\ Email: ${ }^{*}$ mmurguia@santafe-conicet.gov.ar
}

Received 15 March 2015; accepted 26 April 2015; published 4 May 2015

Copyright @ 2015 by authors and Scientific Research Publishing Inc.

This work is licensed under the Creative Commons Attribution International License (CC BY).

http://creativecommons.org/licenses/by/4.0/

\section{(c) (i) Open Access}

\begin{abstract}
A series of $\boldsymbol{N}$-acetylated cationic gemini surfactants (3a-e) having dimeric structures derived from tertiary amines were synthesized. Their antifungal potency and surface properties were determined. It also studied the acute toxicity of the molecule with the best performance and the best water solubility (3e) through Chlorella vulgaris and Daphnia magna bioassays. The results were compared to those obtained for a commercially available reference compound 2-(thiocyanomethylthio) benzothiazole (TCMTB). Parameters such as surface tension $\left(\gamma_{C M C}\right)$, critical micelle concentration $(C M C)$, surface excess concentration $(I)$, and area per molecule $(A)$ were determined. The resulting values indicated that the five gemini surfactants are characterized by good surface-active and self-aggregation properties. All surfactants were tested to evaluate their antifungal activity. Six fungal strains were used to conduct the study. The minimum inhibitory concentration (MIC) value was measured by the fungal growth inhibition. The results of the MICs were compared with two commercially available reference compounds (Fluconazole and TCMTB). The least active molecule was $3 \mathrm{e}$, but $3 \mathrm{~b}$ and $3 \mathrm{~d}$ were found to be the most potent compounds with a similar activity for all strains. Candida albicans was the most sensitive one. In contrast, Aspergillus niger was resistant. Ecotoxicity of gemini 3e was assessed: the commercial formulation (TCMTB) was between three and four orders of magnitude more toxic than the gemini one for the biological species tested.
\end{abstract}

\section{Keywords}

Gemini Surfactants, Surface-Active Properties, Antifungal Activity, Ecotoxicity Bioassays

\footnotetext{
*Corresponding author.

How to cite this paper: Machuca, L.M., Reno, U., Plem, S.C., Gagneten, A.M. and Murguía, M.C. (2015) N-Acetylated Gemini Surfactants: Synthesis, Surface-Active Properties, Antifungal Activity, and Ecotoxicity Bioassays. Advances in Chemical Engineering and Science, 5, 215-224. http://dx.doi.org/10.4236/aces.2015.52023
} 


\section{Introduction}

Fungi are known to cause the decline of various types of organic materials such as paper, textiles, wood, leathers, etc. Fungal biodeterioration consist in changes resulting from the activities of fungi which renders a product unsuitable for its intended use or reduces the economic values of the material [1]. However, to counteract this detrimental effect, the use of numerous substances with different chemical structures and modes of action called "antifungal compounds" increased. Following the onset of antifungal resistance and environmental damage caused by the compounds used at present, the need for developing effective, selective and low environmental impact antifungal is evidenced [2]. Given this scenario, the synthesis of amphiphile molecules with novel properties remains in high demand in the field of applied organic chemistry [3]-[15]. According to the literature and research conducted by our team, gemini surfactants present characteristics and uses that make them very interesting molecules [3] [4] [10] [12]-[15].

The surfactants can be classified according to the nature of their polar groups, to the number of their hydrophobic tails and to their geometric arrangement [3]. Gemini surfactants belong the family of surfactant molecules, which have two long hydrocarbon chains, two ionic groups, and a rigid or flexible spacer [4]. These surfactants usually have better surface-active properties than conventional surfactants with a simple long hydrocarbon chain, and one ionic group.

Gemini compounds are currently being used as surfactants in industrial detergency and have wide field of application, such as skin care, construction of high porosity materials, antibacterial agents, metal-encapped porphyrins, and building blocks for vesicle formation, among others [5]. These compounds could damage the cell membrane of microorganisms as well as inhibit some of its important metabolic processes [6]. Moreover, these compounds are environmentally friendly as they have an excellent biodegradability and low toxicity, an aspect of great importance worldwide [7]-[14].

All these relevant properties have attracted our attention and because of that we are motivated to explore further studies and deepen our knowledge about such compounds [15]-[32]. In our previous work, we reported the synthesis, tensioactive and biological properties of six gemini compounds derived from $N$-acetyldiethanolamines with variable long tails [14]. In this paper we present novel gemini compounds with varying alkyl chains. For example, five synthesized gemini compounds (3a-e) under study are shown in Figure 1. Dimeric (gemini) compounds $\mathbf{3 d}$, and $\mathbf{3 e}$ are novel surfactants.

Their tensioactive properties were determined and their antifungal activity was evaluated using a broth dilution test and were compared to two commercially available references: Fluconazole and 2-(thiocyanomethylthio) benzothiazole (TCMTB). TCMTB is a broad spectrum biocide used to preserve materials. It is very efficient due to its high penetrating power. This substance is effective as a fungicide but it can cause major environmental problems as a consequence of its high toxicity [33] [34]. For this reason it is important to test the toxicity to aquatic organisms of different trophic levels, contributing this way the ecosystem integrity. Freshwater species are suitable for ecotoxicological testing because most surfactants and antimicrobians are discarded as industrial

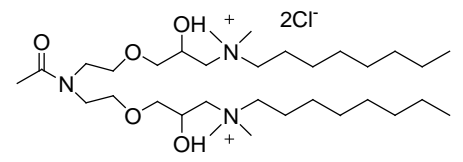

$3 a$

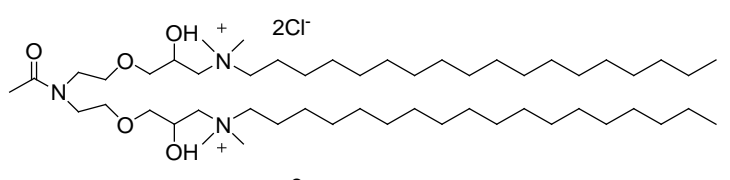

$3 c$

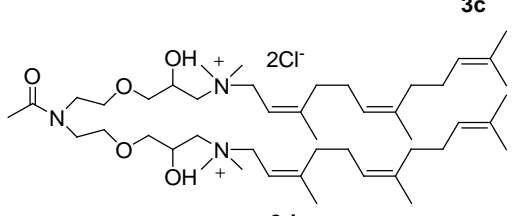

3d

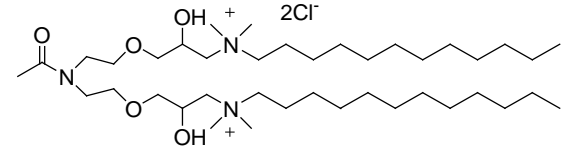

$3 b$

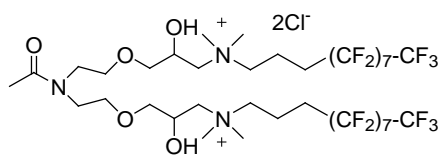

3e

Figure 1. Chemical structures of the dimeric cationic compounds (3a-e) under study. 
effluents or sewage and they can ultimately reach rivers, lakes, and ultimately oceans. In this line, we studied the acute toxicity of the molecule with the best performance using an autotrophic species (C. vulgaris) and a heterotrophic species (D. magna) as biological models.

\section{Experimental Section}

\subsection{General Methods}

All the reagents were commercially available and used as received from the supplier. The solvents were analytical-grade and were purified according to standard methods [35]. The purity and chemical structure of the synthesized compounds were checked by TLC, CG, HRMS, and NMR.

Analytical TLC was performed on a Merck precoated TLC plate (Silica Gel $60 \mathrm{~F}_{254}$ ). Gas chromathographic (GC) analyses were performed on a DANI Master GC chromatograph equipped with a 5\% diphenyl, 95\% dimethylpolysiloxane, low bleed capillary column ( $30 \mathrm{~m} \times 0.53 \mathrm{~mm}, 0.5 \mu \mathrm{m}$ film thickness) and a flame ionization detector. Column Chromatography was performed on silica gel (70 - 230 mesh ASTM) high-purity grade, pore size $60 \AA$. Isolated and authentic compounds were used as internal standards to perform quantitative GC analyses. HRMS were obtained on a Bruker micro QTOF-Q11 mass spectrometer equipped with an electrospray ionization (ESI). ${ }^{1} \mathrm{H}$ NMR (300 MHz), ${ }^{13} \mathrm{C}$ NMR $(75 \mathrm{MHz})$ and ${ }^{19} \mathrm{~F}$ NMR $(300 \mathrm{MHz})$ experiments were recorded on a Bruker Avance 300 spectrometer in $\mathrm{CDCl}_{3}$ using TMS as internal standard. Coupling constants are given in $\mathrm{Hz}$ and chemical shifts are reported in $\delta$ values in $\mathrm{ppm}$. Data are reported as follows: chemical shift, multiplicity ( $\mathrm{s}=$ singlet, $\mathrm{sbr}=$ broad singlet, $\mathrm{d}=$ doublet, $\mathrm{t}=$ triplet, $\mathrm{m}=$ multiplet $)$, coupling constants $(\mathrm{Hz})$, and integration .

\subsection{General Procedure for the Synthesis of Cationic Gemini Surfactants (3a-e)}

The methods and reagents used for the synthesis, purification and characterization of the Bis-alkyldimethylammonium salts (3a-f) were provided for our team [14].

For the development of new gemini cationic compounds ( $\mathbf{3} \mathbf{g}$ and $\mathbf{3 h}$ ) were used $\mathrm{N}, \mathrm{N}$-dimethylfarnesylamine and $N, N$-dimethyl-(4,4,5,5,6,6,7,7,8,8,9,9,10,10,11,11,11-heptadecafluoro-undecyl)amine, respectively. In a glass flask of $100 \mathrm{~mL}$ was added to absolute ethanol $(15 \mathrm{~mL})$ a 2.5:1:0.1 molar mixture of tertiary amines ( $N, N$-dimethyloctylamine $0.601 \mathrm{~g}, N, N$-dimethyldodecylamine $0.815 \mathrm{~g}, N, N$-dimethyloctadecylamine $1.129 \mathrm{~g}$, $N, N$-dimethylfarnesylamine 0.952 g, $N, N$-dimethyl-(4,4,5,5,6,6,7,7,8,8,9,9,10,10,11,11,11-heptadecafluoro-undecyl)amine $1.932 \mathrm{~g}$; i.e., $3.825 \mathrm{mmol})$, diglycidyl ether $2(0.397 \mathrm{~g}, 1.53 \mathrm{mmol})$, and tetrabuthylammonium bromide (TBABr) $(0.049 \mathrm{~g}, 0.153 \mathrm{mmol})$. The solution was stirred for $18 \mathrm{~h}$ at $30^{\circ} \mathrm{C}$ and the solvent was evaporated under reduced pressure. Then, the unreacted tertiary amine was removed by column chromatography with ethyl acetate/ethanol/water/ammonium hydroxide $28 \mathrm{wt} \%$ (4:1:0.25:0.5) solvents as eluant. The desired products were confirmed by TLC and the solvent evaporated. For each gemini compounds, the addition of two equivalents of hydrochloric acid, provided the corresponding counterions. Lastly, the five products (3a-e) were lyophilized. This procedure yielded 3a, 3b, 3c, 3d, and $\mathbf{3 e}$ as isolated pure compounds, in 92, 61, 39, 30, and 45\%, respectively.

\subsection{The Physical Data of the Synthesized Products Are as Follows}

The physical data for gemini compounds $\mathbf{3 a}$, $\mathbf{3 b}$, and $\mathbf{3} \mathbf{c}$ were reported by us in a previous paper (Murguía et al 2008) [14]. The gemini surfactants $\mathbf{3 d}$, and $\mathbf{3 e}$ are new compounds.

2.3.1. $N, N$-Bis[2-(3-octyldimethylammonio-2-hydroxypropoxy)ethyl]acetamide Dichloride (3a) Oil pale yellow (92\%) [14]. IR (KBr): $v=760.0,930.2,1120.1,1460.4,1620.0,2850.1,2930.3,3450.0 \mathrm{~cm}^{-1}$. ${ }^{1} \mathrm{H}$ NMR [200 MHz, $\left.\left(\mathrm{D}_{2} \mathrm{O}\right)\right]: \delta=0.81-0.93(\mathrm{~m}, 10 \mathrm{H}), 1.25-1.45(\mathrm{~m}, 16 \mathrm{H}), 1.94-1.97(\mathrm{~m}, 4 \mathrm{H}), 2.05(\mathrm{~s}, 3 \mathrm{H})$, 3.12 - 3.14 (m, 6H), 3.23 - 3.27 (m, 4H), 3.32 (s, 12H), 3.35 - 3.45 (m, 4H), 3.53 - 3.56 (m, 4H), 3.80 - $4.02(\mathrm{~m}$, 6H). ${ }^{13} \mathrm{C}$ NMR [50 MHz]: $\delta=14.0,20.7,22.7,24.1,26.3,27.2,28.4,31.7,41.6,44.6,59.4,63.5,64.8,66.9$, 70.1, 70.2, 169.1. HRMS (ESI $)(\mathrm{M}-\mathrm{Cl})^{+}$: Calcd. for $\mathrm{C}_{32} \mathrm{H}_{69} \mathrm{Cl}_{2} \mathrm{~N}_{3} \mathrm{O}_{5}$ : 611.3727. Found: 611.3716.

2.3.2. $N$, $N$-Bis[2-(3-dodecyldimethylammonio-2-hydroxypropoxy)ethyl]acetamide Dichloride (3b) White waxy product (61\%) [14]. IR (KBr): $v=760.1,930.4,1120.0,1460.0,1620.5,2850.0,2930.1,3450.2$ $\mathrm{cm}^{-1} .{ }^{1} \mathrm{H}$ NMR [200 MHz, $\left.\left(\mathrm{D}_{2} \mathrm{O}\right)\right]: \delta=0.84-0.91(\mathrm{~m}, 10 \mathrm{H}), 1.22-1.40(\mathrm{~m}, 32 \mathrm{H}), 1.94-2.01(\mathrm{~m}, 4 \mathrm{H}), 2.06(\mathrm{~s}$, 3H), 3.12 - 3.16 (m, 6H), 3.25 - 3.27 (m, 4H), 3.32 (s, 12H), 3.36 - 3.45 (m, 4H), 3.53 - 3.57 (m, $4 \mathrm{H}), 3.79$ - 4.04 
(m, 6H). ${ }^{13} \mathrm{C}$ NMR [50 MHz]: $\delta=14.1,20.7,22.6,23.8,26.1,27.9,29.4,29.45,29.6,29.6,31.7,41.6,44.6$, 44.7, 59.4, 63.5, 64.8, 66.3, 70.1, 70.2, 169.1. HRMS (ESI ${ }^{+}$(M-Cl) ${ }^{+}$: Calcd. For $\mathrm{C}_{40} \mathrm{H}_{85} \mathrm{Cl}_{2} \mathrm{~N}_{3} \mathrm{O}_{5}$ : 723.5886 . Found: 723.5875 .

2.3.3. $\mathrm{N}, \mathrm{N}$-Bis[2-(3-octadecyldimethylammonio-2-hydroxypropoxy)ethyl]acetamide Dichloride (3c) White waxy product (39\%) [14]. IR (KBr): $v=760.0,930.1,1120.0,1460.0,1620.2,2850.1,2930.0,3450.0$ $\mathrm{cm}^{-1} .{ }^{1} \mathrm{H}$ NMR [200 MHz,(D2O)]: $\delta=0.83-0.90(\mathrm{~m}, 10 \mathrm{H}), 1.21-1.40(\mathrm{~m}, 56 \mathrm{H}), 1.94-1.98(\mathrm{~m}, 4 \mathrm{H}), 2.05(\mathrm{~s}$, $3 \mathrm{H}), 3.12$ - $3.16(\mathrm{~m}, 6 \mathrm{H}), 3.25$ - $3.27(\mathrm{~m}, 4 \mathrm{H}), 3.32(\mathrm{~s}, 12 \mathrm{H}), 3.38$ - $3.45(\mathrm{~m}, 4 \mathrm{H}), 3.53$ - $3.56(\mathrm{~m}, 4 \mathrm{H}), 3.79$ - 4.04 (m, 6H). ${ }^{13} \mathrm{C}$ NMR [50 MHz]: $\delta=13.1,19.7,20.7,23.8,26.1,26.8,27.8,29.2,29.3,29.3,29.4,29.4,29.62$, 29.6, 29.7, 29.7, 32.0, 41.6, 44.6, 59.4, 63.5, 64.8, 66.9, 70.1, 70.2, 169.1. HRMS (ESI $\left.{ }^{+}\right)(\mathrm{M}-\mathrm{Cl})^{+}$: Calcd. for $\mathrm{C}_{52} \mathrm{H}_{109} \mathrm{Cl}_{2} \mathrm{~N}_{3} \mathrm{O}_{5}$ : 891.9125. Found: 891.9113.

2.3.4. $N, N$-Bis[2-(3-farnesyldimethylammonio-2-hydroxypropoxy)ethyl]acetamide Dichloride (3d) Yellow waxy product (30\%). IR (KBr): $v=1085.9,2940.0,3640.0 \mathrm{~cm}^{-1} .{ }^{1} \mathrm{H}$ NMR [200 MHz, $\left.\left(\mathrm{CDCl}_{3}\right)\right]: \delta$ $=1.63(\mathrm{~s}, 18 \mathrm{H}), 1.69(\mathrm{~s}, 6 \mathrm{H}), 1.96-2.02(\mathrm{~m}, 16 \mathrm{H}), 2.05(\mathrm{~s}, 3 \mathrm{H}) 3.14-3.54(\mathrm{~m}, 12 \mathrm{H}), 3.32(\mathrm{~s}, 12 \mathrm{H}), 3.87-4.06(\mathrm{~m}$, $10 \mathrm{H}), 5.04-5.10(\mathrm{~m}, 6 \mathrm{H}) .{ }^{13} \mathrm{C}$ NMR $[50 \mathrm{MHz}]: \delta=15.2,17.5,22.0,23.2,24.26,25.5,27.0,34.2,38.5,39.9$, 41.1, 53.6, 60.9, 62.7, 63.1, 66.9, 68.8, 71.2, 98.3, 124.2, 124.9, 129.9, 135.3, 144.6, 169.2. HRMS (ESI $\left.{ }^{+}\right)(\mathrm{M} / 2-$ $\mathrm{Cl})^{+}$: Calcd. for $\mathrm{C}_{46} \mathrm{H}_{85} \mathrm{Cl}_{2} \mathrm{~N}_{3} \mathrm{O}_{5}$ : 397.8270, Found: 398.2815.

\subsection{5. $N, N$-Bis $\{2-[3-(4,4,5,5,6,6,7,7,8,8,9,9,10,10,11,11,11)-$}

heptadecafluoroundecyldimethylamm-onio-2-hydroxypropoxy] ethyl\}acetamide (3e)

White waxy product (45\%). IR (KBr): $v=1085.9,2940.0,3640.0 \mathrm{~cm}^{-1} .{ }^{1} \mathrm{H}$ NMR [200 MHz, $\left.\left(\mathrm{CDCl}_{3}\right)\right]: \delta=2.05$ (s, 3H), $2.22-2.34(\mathrm{~m}, 8 \mathrm{H}), 3.23-3.54(\mathrm{~m}, 16 \mathrm{H}), 3.34(\mathrm{~s}, 12 \mathrm{H}), 3.84-4.04(\mathrm{~m}, 6 \mathrm{H}) .{ }^{13} \mathrm{C}$ NMR [50 MHz, $\left.\left(\mathrm{CDCl}_{3}\right)\right]: \delta=14.0,22.8,25.9,28.9,29.2,29.5,29.6,29.9,32.2,42.2,62.7,64.1,70.1,71.1,72.7,73.7,98.3$, 110.4, 115.2, 126.6, 130.5, 169.1. ${ }^{19} \mathrm{~F}$ NMR [200 MHz, $\left.\left(\mathrm{CD}_{3} \mathrm{OD} / \mathrm{CFCl}_{3}\right)\right]: \delta=-82.0\left(\mathrm{~m}, 6 \mathrm{~F}, 2 \mathrm{CF}_{3}\right),-115.1(\mathrm{~m}$, 4F, 2CF $),-123.1\left(\mathrm{~m}, 12 \mathrm{~F}, 6 \mathrm{CF}_{2}\right),-123.3\left(\mathrm{~m}, 4 \mathrm{~F}, 2 \mathrm{CF}_{2}\right),-124.0\left(\mathrm{~m}, 4 \mathrm{~F}, 2 \mathrm{CF}_{2}\right),-124.9\left(\mathrm{~m}, 4 \mathrm{~F}, 2 \mathrm{CF}_{2}\right),-127.5$ (m, 4F, 2CF $)$. HRMS (ESI ${ }^{+}$) (M/Z-Cl) $)^{+}$: Calcd. for $\mathrm{C}_{38} \mathrm{H}_{49} \mathrm{~F}_{34} \mathrm{Cl}_{2} \mathrm{~N}_{3} \mathrm{O}_{5}$ : 654.6115. Found: 654.6095.

\subsection{Surface Properties}

The surface tension was measured at $20^{\circ} \mathrm{C}$ and $\mathrm{pH}=7$ using a semiautomatic tensiometer (Cole-Parmer Surface Tensiomat 21) by the Du Nouy ring method [36]. It was calibrated against differents pure liquids and the surface tension of each concentration of aqueous solution was measured three times. The critical micelle concentration $(C M C)$ values for each gemini surfactants were determined and estimated from the breakpoint of each surface tension versus concentration (on log scale) curves [14].

\subsection{Antifungal Activities}

The antifungal activity of the cationic gemini compounds (3e-3g-3h) were evaluated using the applied method by National Committee for Clinical Laboratory Standards (NCCLS) [37] [38]. Sabouraud dextrose broth (Britania S.A) was used as culture media. Fluconazole and TCMTB were used as drugs for positive control. Minimum inhibitory concentrations (MIC) were expressed in $\mu \mathrm{g} \mathrm{mL}^{-1}$. Four strains of microorganism were used: Candida parapsilosis (ATCC 22019), Candida albicans (ATCC 64548), Aspergillus niger (ATCC 16404), a wild-type strain of Alternaria sp. It is considered important to note that the antifungal activity of compound $3 \mathbf{e}$ was evaluated against the last two mentioned filamentous fungi. Its performance against yeasts was also reported previously [14]. The concentration range used $\left(64-0.03125 \mu \mathrm{g} \cdot \mathrm{mL}^{-1}\right.$ ) as well as the checks in the trials (drug-free and fungus-free controls) for water soluble gemini were the same as those employed for (3d-f) surfactants [14]. All the tests were performed with two replicates.

\subsection{Microalgae Ecotoxicity Bioassays}

As will be seen later, the MIC values obtained for $\mathbf{3 a}$, 3c, 3d, and 3e molecules were higher in comparison to those found for gemini $\mathbf{3 b}$. Consequently, and given its low production cost and its good water solubility, we decided to investigate the environmental impact of $\mathbf{3 b}$ compared to TCMTB. The acute toxicities of TCMTB (commercial solution, $30 \% \mathrm{w} / \mathrm{w}$ ) and of the gemini product with better performance (3b) ( $80 \%$ purity) were 
assessed by determining the half maximal effective concentration at $96 \mathrm{~h}$ (96 h-EC50).

\subsubsection{Culture Conditions}

The Chlorella vulgaris (CLV2) strain originated from an algae culture collection maintained at the Scientific Research and Superior Education Center of Ensenada, Baja California, México (CICESE). The cultures were grown for 10 days in $2000 \mathrm{~mL}$ flasks in sterile conditions using Bold Basal Medium (BBM) [39].

The $\mathrm{pH}$ of the culture was 6.25 . The culture was maintained at a constant temperature $\left(23^{\circ} \mathrm{C} \pm 1^{\circ} \mathrm{C}\right)$, with uniform and continuous aeration and light $\left(0.72 \times 10^{20}\right.$ photons $\left.\mathrm{m}^{-2} \cdot \mathrm{s}^{-1} \pm 20 \%\right)$. Continuous stirring of the culture was achieved using a $100 \mathrm{rpm}$ magnetic plate.

\subsubsection{Growth Inhibition Tests}

The experimental treatments of growth inhibition with C. vulgaris were performed according to USEPA standard protocol [40]. Microalgae were harvested during the exponential growth phase (day 7), before being centrifuged twice (10 min at $3500 \mathrm{rpm})$ and re-suspended in sterile ultrapure water. The concentration of algae in the culture was assessed directly using a Neubauer hemocytometer chamber $\left(1.02 \times 106 \mathrm{cells} \mathrm{mL}^{-1}\right)$ and indirectly using a spectrophotometric method (absorbance $1.5 \lambda$ at $650 \mathrm{~nm}$, using a Hatch spectrophotometer). The bioassays were conducted in $250 \mathrm{ml}$ flasks containing $100 \mathrm{~mL}$ of BBM medium and an initial cell density of $10^{4}$ cells $\mathrm{mL}^{-1}$.

Different TCMTB and 3e products concentrations were added to the algae culture, all trials triplicated per control and concentrations tested. The following concentrations of TCMTB were used: $1.562 \times 10^{-4} \mathrm{mg} \cdot \mathrm{L}^{-1}$, $3.125 \times 10^{-4} \mathrm{mg} \cdot \mathrm{L}^{-1}, 6.250 \times 10^{-4} \mathrm{mg} \cdot \mathrm{L}^{-1}, 1.250 \times 10^{-3} \mathrm{mg} \cdot \mathrm{L}^{-1}, 2.5 \times 10^{-3} \mathrm{mg} \cdot \mathrm{L}^{-1}, 5.0 \times 10^{-3} \mathrm{mg} \cdot \mathrm{L}^{-1}, 0.01$ $\mathrm{mg} \cdot \mathrm{L}^{-1}, 0.02 \mathrm{mg} \cdot \mathrm{L}^{-1}$ and a control. The following $3 \mathbf{b}$ concentrations were used: $0.08 \mathrm{mg} \cdot \mathrm{L}^{-1}, 0.16 \mathrm{mg} \cdot \mathrm{L}^{-1}, 0.32$ $\mathrm{mg} \cdot \mathrm{L}^{-1}, 0.64 \mathrm{mg} \cdot \mathrm{L}^{-1}, 1.28 \mathrm{mg} \cdot \mathrm{L}^{-1}, 2.56 \mathrm{mg} \cdot \mathrm{L}^{-1}, 5.12 \mathrm{mg} \cdot \mathrm{L}^{-1}$ and a control.

The vessels were maintained in an incubation chamber, under controlled conditions, as follows: temperature $=$ $23^{\circ} \mathrm{C} \pm 1^{\circ} \mathrm{C}$, daily shaking, and continuous lighting $\left(0.72 \times 10^{20}\right.$ photons $\left.\mathrm{m}^{-2} \mathrm{~s}^{-1} \pm 20 \%\right)$. The $\mathrm{pH}$ values were measured at the beginning and the end of each assay. For each of the compounds, effective concentration at 96 hours (96hs-EC50) was determined by linear interpolation [40]. To determine the EC50, the cell density (cells $\mathrm{ml}^{-1}$ ), was plotted against the products concentration and analyzed using the Probalg Program [41].

\subsection{Daphnia magna Acute Ecotoxicity Bioassays}

The D. magna specimens were generated from a monoclonal culture, which was initiated with an adult female and maintained in the laboratory for several generations under controlled temperature and photoperiod conditions. The test medium used both to maintain the stock culture and for developing the assays was reconstituted hard water which includes [42]: $2.4 \mathrm{~g} \mathrm{MgSO}_{4}, 3.84 \mathrm{~g} \mathrm{NaHCO}, 0.16 \mathrm{~g} \mathrm{KCl}$ and $2.4 \mathrm{~g} \mathrm{CaSO}_{4} \cdot 2 \mathrm{H}_{2} \mathrm{O}$, dissolved in $20 \mathrm{~L}$ of distilled water. All experiments were initiated with neonates $(<24 \mathrm{~h}$ old). Ten neonates per treatment per $30 \mathrm{~mL}$ of test solution were used. Five concentrations, all triplicated, were tested [43]; the animals were not fed during the tests and maintained in a growth chamber under controlled and constant conditions (photoperiod $16 \mathrm{~L}$ : $8 \mathrm{O}$ and $\mathrm{T} 20^{\circ} \mathrm{C} \pm 1^{\circ} \mathrm{C}$ ).

Oxygen concentrations and $\mathrm{pH}$ were determined at 0,24 , and $48 \mathrm{~h}$ to ensure levels accepted by the protocol (EPA 2002) [44]. Number of mobile and immobile specimens was registered as alive and dead, recognized as immobilization for $15 \mathrm{~s}$ after stimulation by smooth movement. The Effective Concentration that killed half of the experimental population (EC50) at 24 and $48 \mathrm{~h}$ for each of the compounds was calculated using the PROBIT program [45].

\section{Results and Discussion}

\subsection{Design and Synthesis of Cationic Gemini Surfactants (3a-e)}

The cationic gemini surfactants (3a-e) were prepared following the two-step procedure described by Murguía et al. and showing in Scheme 1 [14]. The intermediate $\mathbf{2}$ was obtained by etherification of diethanolamine $\mathbf{1}$ with ( \pm )-epichlorohydrin. $N$-acetylated compounds (3a-e) were synthesized via oxirane ring opening with tertiary amines. This procedure yielded 3a, 3b, 3c, 3d, and $\mathbf{3 e}$ as isolated pure compounds, in $92 \%, 61 \%$, 39\%, 30\%, and $45 \%$, respectively. The structures of the compounds were confirmed by analytical methods such as: IR, ${ }^{1} \mathrm{H}$ NMR, 
${ }^{13} \mathrm{C}$ NMR, and HRMS.

\subsection{Surface Activity and Aggregation Data of Synthesized Cationic Surfactants}

Surface tension of gemini surfactants (3a-e) with a $\mathrm{C}_{8}-\mathrm{C}_{12}-\mathrm{C}_{18}$ long tail and varying alkyl chains -saturated, unsaturated, and fluorinated- at $\mathrm{pH} 7^{\circ} \mathrm{C}$ and $20^{\circ} \mathrm{C}$ are shown in Figure 2.

All parameters studied: $C M C, \gamma_{\mathrm{CMC}}, p C_{20}$ and $C_{20}$, the ratio of $C M C / C_{20}, \Gamma$, and $A$, are summarized in Table 1 . These values are in agreement with those characterizing the proper quantitative behavior of moderate to good surfactants. The $p C_{20}$ values indicate that the three dimeric cationic compounds are good surfactants, especially 3e. The $C M C / C_{20}$ values show a great capability of compounds $3 \mathbf{d}$ (32.86) and $3 \mathbf{e}$ (25.87) to be adsorbed at the interfaces in comparative with $\mathbf{3 b}$ (5.99). The $\Gamma$ and $A$ parameters vary with the molecular structure. The area per molecule at air/water interface of the gemini surfactants was found in a range of $78.88-148.24 \AA^{2}$. From the series, it is intended to highlight the behavior of 3c, and 3e with $p C_{20}$ value of 4.31 and 4.61 (CMC of $0.22 \mathrm{mM}$ and $0.62 \mathrm{mM}$ ), respectively. In conclusion, the described behavior indicates that all cationic dimeric surfactants (3a-e) satisfy the primary requirement of being good surfactants.

\subsection{Antifungal Activities}

The biological activity (MICs) of gemini compounds (3a-e) was obtained in comparison to Fluconazole and

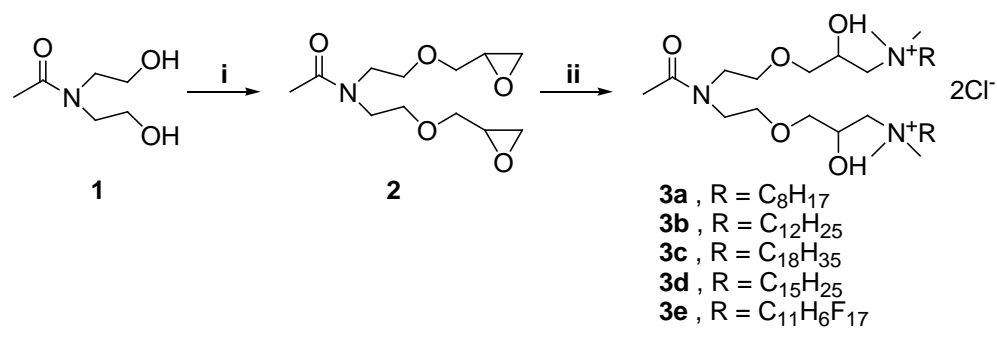

Scheme 1. Synthesis of the dimeric cationic compounds (3a-e). Reagents and conditions: (i): $1,( \pm)$-epichlorohydrin, aq. $\mathrm{NaOH}$, tetrabuthylammonium hydrogen sulfate, $30^{\circ} \mathrm{C}, 5 \mathrm{~h}$; (ii): 2 , N,N-dimethylamines, $\mathrm{TBABr}$, ethanol, $30^{\circ} \mathrm{C}$, $18 \mathrm{~h}$.

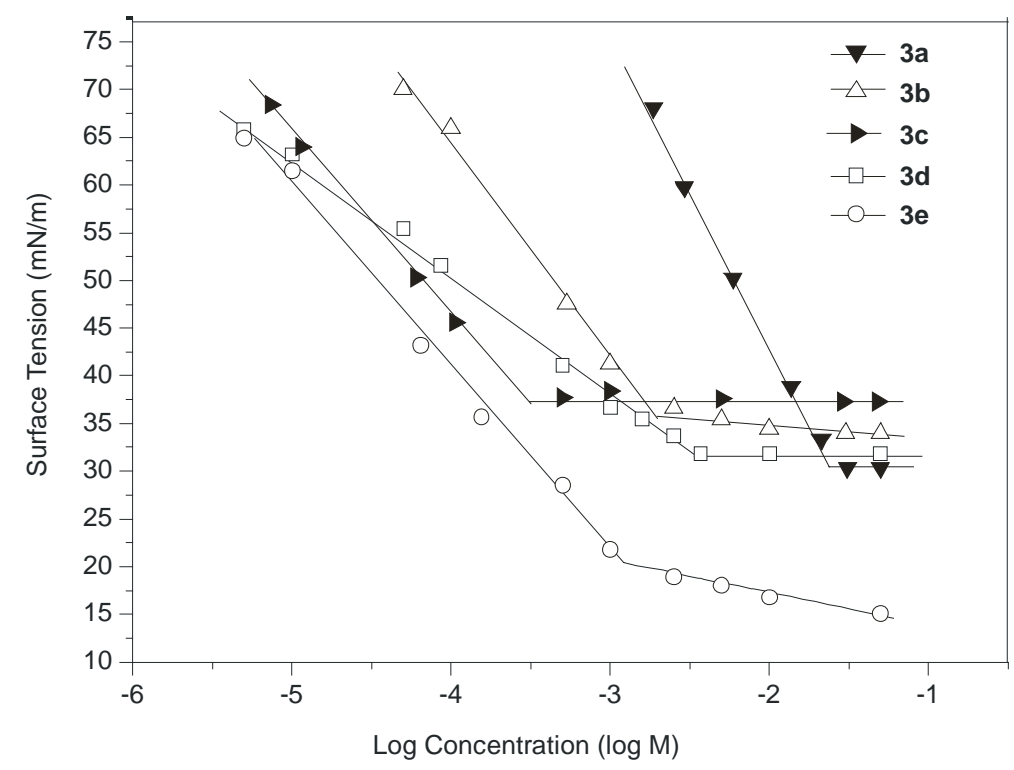

Figure 2. Surface tension vs. logarithm of the aqueous molar concentration $(\log C)$ of cationic gemini surfactants (3a-e). 
TCMTB against Candida parapsilosis (ATCC 22019), Candida albicans (ATCC 64548), Aspergillus niger (ATCC 16404) and Alternaria sp. (Table 2).

Gemini $3 \mathbf{b}$ was found to be the most potent compounds with a similar activity for all strains. In general, the less active molecule was 3e. This behavior could be due to the high electronegativity of fluorine atoms, which would cause the two tails in the molecule repel each other. The results showed that $C$. albicans (ATCC 64548) was the most sensitive strain. In contrast, A. niger (ATCC 16404) was resistant. Results obtained for gemini compounds were better to antifungals as Fluconazole and TCMTB, and in some cases greater than these model compounds.

\subsection{Ecotoxicity Bioassays}

Table 3 summarizes the 96 h-EC50 obtained with C. vulgaris and the 24 and 48 h-EC50 obtained with D. mag$n a$ after exposure to TCMTB and gemini compound 3e. Daphnia magna bioassays showed that with TCMTB

Table 1. Surface activity and aggregation data of synthesized cationic surfactants ${ }^{\mathrm{a}}$.

\begin{tabular}{cccccccc}
\hline Compound & $\mathrm{CMC}^{\mathrm{b}}(\mathrm{mM})$ & $\mathrm{C}_{20}(\mathrm{mM})$ & $\gamma_{\mathrm{CMC}}(\mathrm{mN} / \mathrm{m})$ & $\mathrm{pC}_{20}$ & $\mathrm{CMC}_{2} \mathrm{C}_{20}$ & $\Gamma \times 10^{6}\left(\mathrm{~mol} / \mathrm{m}^{2}\right)$ & $\mathrm{A} \times 10^{20}\left(\mathrm{~m}^{2}\right)$ \\
\hline 3a & 34.79 & 5.47 & 31.84 & 2.26 & 6.35 & 2.10 & 78.88 \\
3b & 2.45 & 0.41 & 34.58 & 3.39 & 5.99 & 1.85 & 90.14 \\
3c & 0.22 & 0.05 & 39.24 & 4.31 & 4.47 & 1.58 & 105.18 \\
3d & 2.92 & 0.09 & 31.84 & 4.04 & 32.86 & 1.12 & 148.24 \\
3e & 0.62 & 0.02 & 19.22 & 4.61 & 25.87 & 2.01 & 82.60 \\
\hline
\end{tabular}

${ }^{\mathrm{a}}$ Experimental conditions: temperature $20^{\circ} \mathrm{C} \pm 0.5^{\circ} \mathrm{C}$. Aqueous solution at $\mathrm{pH}=7$. Experimental uncertainties are estimated to be $\pm 0.03 \mathrm{mM}$ on $C M C$ and $\pm 1 \mathrm{mN} \mathrm{m}^{-1}$ on $\gamma_{\mathrm{CMC}}$ values. b. The critical micelle concentration (CMC) values were determined using a series of aqueous solutions at various concentrations, and estimated from the break point of each surface tension versus concentration (on log scale) curves. The ability of these compounds to lower surface tension at the $C M C\left(\gamma_{C M C}\right)$ and reduced by $20 \mathrm{mN} / \mathrm{m}\left(C_{20}\right.$ or $\left.p C_{20}\right)$ were calculated there from. The optimal cross-section surface area $A$ occupied by the surfactant head group at the air/water interface was estimated from the surface excess concentration, $\Gamma$. The latter one was calculated by applying the Gibbs adsorption isotherm equation: $\Gamma=-(1 / n 2.303 \mathrm{RT})(\mathrm{d} \gamma / \mathrm{d} \log C)$, where $\gamma$ is the surface tension and $C$ is the surfactant concentration and $n$ equals 2. The area per molecule at the interface was calculated from $A=1 / N \Gamma$ where $N$ is Avogadro's number [36].

Table 2. Antifungal activity of cationic gemini surfactants (3a-e) with a similar long tail and varying alkyl chains synthesized.

\begin{tabular}{cccccc}
\hline \multirow{2}{*}{ Compound } & \multicolumn{5}{c}{$(\mathrm{MIC})\left(\mu \mathrm{g} \cdot \mathrm{mL}^{-1}\right)$} \\
\cline { 2 - 6 } & $\mathrm{R}$ & $\begin{array}{c}\text { C. parapsilosis } \\
\text { ATCC } 22019\end{array}$ & $\begin{array}{c}\text { C. albicans } \\
\text { ATCC } 64548\end{array}$ & $\begin{array}{c}\text { A. niger } \\
\text { ATCC } 16404\end{array}$ & Alternaria sp. \\
\hline 3a & $-\mathrm{C}_{8} \mathrm{H}_{17}$ & $>64$ & $>64$ & $>64$ & $>64$ \\
3b & $-\mathrm{C}_{12} \mathrm{H}_{25}$ & 8 & 8 & 32 & 32 \\
3c & $-\mathrm{C}_{12} \mathrm{H}_{25}$ & 16 & 8 & 32 & 8 \\
3d & $-\mathrm{C}_{15} \mathrm{H}_{25}$ & 32 & 16 & 64 & 64 \\
3e & $-\mathrm{C}_{11} \mathrm{H}_{6} \mathrm{~F}_{17}$ & 256 & 256 & $>512$ & 64 \\
Fluconazole & - & 16 & $<5$ & $>512$ & 32 \\
TCMTB & - & 64 & 16 & 32 & 16 \\
\hline
\end{tabular}

Table 3. 96 h-EC50 obtained with C. vulgaris and 24 and 48 h-EC50 obtained with D. magna after exposure to TCMTB and gemini compound 3e.

\begin{tabular}{cccc}
\hline & Chlorella vulgaris & Daphnia magna & Daphnia magna \\
\cline { 2 - 4 } Compound & $96 \mathrm{~h}-\mathrm{EC} 50$ & $24 \mathrm{~h}-\mathrm{EC} 50$ & $48 \mathrm{~h}-\mathrm{EC} 50$ \\
TCMTB & $2.172 \times 10^{-4} \mathrm{mg} \cdot \mathrm{L}^{-1}$ & $0.00034 \mathrm{mg} \cdot \mathrm{L}^{-1}$ & $0.0001 \mathrm{mg} \cdot \mathrm{L}^{-1}$ \\
3e & $0.1765 \mathrm{mg} \cdot \mathrm{L}^{-1}$ & $1.234 \mathrm{mg} \cdot \mathrm{L}^{-1}$ & $0.474 \mathrm{mg} \cdot \mathrm{L}^{-1}$ \\
\hline
\end{tabular}


at 24 and $48 \mathrm{~h}$-EC50 were $3 \times 10^{-4} \mathrm{mg} \cdot \mathrm{L}^{-1}$ and $1 \times 10^{-4} \mathrm{mg} \cdot \mathrm{L}^{-1}$, respectively. Conversely, with compound $3 \mathbf{e}$ at 24 and $48 \mathrm{~h}$-EC50 were $1.234 \mathrm{mg} \cdot \mathrm{L}^{-1}$ and $0.474 \mathrm{mg} \cdot \mathrm{L}^{-1}$, respectively. TCMTB was more toxic to Daphnia magna. Conversely, $3 \mathbf{e}$ was more toxic to Chlorella vulgaris. C. vulgaris biossays showed that with TCMTB the EC50 was $2.172 \times 10^{-4} \mathrm{mg} \cdot \mathrm{L}^{-1}$ and with $3 \mathbf{e}$ the EC50 was $0.6568 \mathrm{mg} \cdot \mathrm{L}^{-1}$. The commercial formulation was between three and four orders of magnitude more toxic than the gemini one for the species tested. These results highlight the importance of promoting the synthesis of compounds less harmful to the environment.

For the first time, the molecule with the better performance (3e) was tested to evaluate its ecotoxicity using Chlorella vulgaris and Daphnia magna. Results were compared to those obtained for a commercially available reference compound TCMTB. The decrease in effluent toxicity using test organisms has proved to be very useful in many industries [46]-[48].

Compound 3e was found to be a very potent compound in comparison with the commercial one [49]. In this line, the development of high performance surface-active agents seems to continue to be of great interest of the academic and industrial communities, as it necessary to develop less harmful compounds, and to reduce toxicity in order to protect the aquatic environment [15].

\section{Conclusion}

We have shown that it is possible to synthesize five symmetrical gemini surfactants derived from $N$-acetyldiethanolamines with two long tails $\left(\mathrm{C}_{8}-\mathrm{C}_{12}-\mathrm{C}_{18}\right)$ and variable alkyl chains (saturated, unsaturated, and fluorinated). These surfactants can be synthesized by a two-step reaction with good to excellent yields (30\% - 92\%). Their tensioactive properties were determinated and the described behavior indicates that all cationic dimeric surfactants (3a-e) satisfy the primary requirement of being good surfactants. Their antifungal activities were evaluated and were compared to two commercially available references (Fluconazole and TCMTB). Results obtained for gemini compounds were better to antifungals as Fluconazole and TCMTB. Ecotoxicity bioassays were studied using the acute toxicity of the molecule with the best performance (3b) using an autotrophic species (C. vulgaris) and a heterotrophic species (D. magna) as biological models. Results were compared to those obtained for a commercially available reference compound TCMTB. The gemini surfactant $\mathbf{3 b}$ was found to be a very potent compound in comparison with the commercial one. In this line, the development of high performance surfaceactive agents seems to continue in order to be of great interest for the academic and industrial communities. Also, it is necessary to develop less harmful compounds to reduce toxicity in order to protect the aquatic environment.

\section{Acknowledgements}

The present work is partially supported by the National Ministry of Science and Technology (MINCyT), the Agencia Nacional de Promoción Científica y Tecnológica (ANPCyT), the National Council of Science and Technology (CONICET), and the National University of Litoral (UNL) of Argentina.

\section{References}

[1] Orlita, A. (2004) Microbial Biodeterioration of Leather and Its Control: A Review. International Biodeterioration \& Biodegradation, 53, 157-163. http://dx.doi.org/10.1016/S0964-8305(03)00089-1

[2] Abad, M.J., Ansuategui, M. and Bermejo, P. (2007) Active Antifungal Substances from Natural Sources. ARKIVOC, vii, 116-145.

[3] Menger, F.M. and Keiper, J.S. (2000) Gemini Surfactants. Angewandte Chemie International Edition, 39, $1906-1920$. http://dx.doi.org/10.1002/1521-3773(20000602)39:11<1906::AID-ANIE1906>3.0.CO;2-Q

[4] Zana, R. (2002) Dimeric (Gemini) Surfactants: Effect of the Spacer Group on the Association Behavior in Aqueous Solution. Journal of Colloid and Interface Science, 248, 203-251. http://dx.doi.org/10.1006/jcis.2001.8104

[5] Zana, R. and Xia, J. (2004) Gemini Surfactants. Surfactant Science Series. Marcel Dekker, New York

[6] Menger, F.M. and Migulin, V.A. (1999) Synthesis and Properties of Multiarmed Geminis. The Journal of Organic Chemistry, 64, 8916-8921. http://dx.doi.org/10.1021/jo9912350

[7] Menger, F.M. and Mbadugha, B.N.A. (2001) Gemini Surfactants with a Disaccharide Spacer. Journal of the American Chemical Society, 123, 875-885. http://dx.doi.org/10.1021/ja0033178

[8] Zhu, Y., Masuyama, A., Kirito, Y., Okahara, M. and Rosen, M.J. (1992) Preparation and Properties of Glycerol Based Double or Triple-Chain Surfactants with Two Hydrophilic Ionic Groups. Journal of the American Oil Chemists Society, 69, 626-632. http://dx.doi.org/10.1007/BF02635800 
[9] Devínsky, F., Lacko, L., Mlynarcik, D., Racansky, V. and Krasnec, L. (1985) Relationship between Critical Micelle Concentration and Minimum Inhibitory Concentrations for Some None-Aromatic Quaternary Ammonium Salts and Amine Oxides. Tenside Detergents, 22, 10-15.

[10] Murguía, M.C. and Grau, R.J. (2001) Synthesis of New Pentaerythritol-Based Gemini Surfactants. Synlett, 8, 12291232. http://dx.doi.org/10.1055/s-2001-16060

[11] Murguía, M.C., Vaillard, S.E. and Grau, R.J. (2001) A Facile, Selective Preparation of Monoketals from Pentaerythritol and Ketones. Synthesis, 7, 1093-1097. http://dx.doi.org/10.1055/s-2001-14569

[12] Murguía, M.C., Cabrera, M.I. and Grau, R.J. (2002) Selective Preparation of Key Intermediates for the Synthesis of Gemini Surfactants by Phase-Transfer Catalysis. Reaction Kinetics and Catalysis Letters, 75, 205-211. http://dx.doi.org/10.1023/A:1015219825198

[13] Murguía, M.C., Cabrera, M.I., Guastavino, J.F. and Grau, R.J. (2005) New Oligomeric Surfactants with Multiple-Ring Spacers: Synthesis and Tensioactive Properties. Colloids and Surfaces A: Physicochemical and Engineering Aspects, 262, 1-7. http://dx.doi.org/10.1016/j.colsurfa.2005.03.018

[14] Murguía, M.C., Machuca, L.M., Lurá, M.C., Cabrera, M.I. and Grau, R.J. (2008) Synthesis and Properties of Novel Antifungal Gemini Compound Derived from N-Acetyl Diethanolamines, Journal of Surfactants and Detergents. 11, 223-230. http://dx.doi.org/10.1007/s11743-008-1076-4

[15] Sánchez, V.G., Giudici, C.J., Bassi, A.R. and Murguía, M.C. (2012) Synthesis, Surface-Active Properties, and Anthelmintic Activities of New Cationic Gemini Surfactants against the Gastrointestinal Nematode, Heligmosomoides polygyrus bakeri, in Vitro. Journal of Surfactants and Detergents, 15, 463-470. http://dx.doi.org/10.1007/s11743-012-1337-0

[16] Kopecky, F. (1996) Micellization and Other Associations of Amphiphilic Antimicrobial Quaternary Ammonium Salts in Aqueous Solutions. Die Pharmazie, 51, 135-144.

[17] Dubnicková, M., Pisárcik, M., Lacko, I., Devínsky, F., Mlynarcik, D. and Balgavý, P. (1997) Gemini Amphiphiles: Antimicrobial Activity, Micellization and Interaction with Phospholipid Bilayers. XIIIth School on Biophysics of Membrane Transport, Cellular and Molecular Biology Letters, 2, (Suppl. 1), 215-216.

[18] Dubničková, M., Yaradaikin, S., Lacko, I., Devínsky, F., Gordeliy, V. and Balgavý, P. (2004) Effects of Gemini Surfactants on Egg Phosphatidylcholine Bilayers in the Fluid Lamellar Phase. Colloids and Surfaces B: Biointerfaces, 34, 161-164. http://dx.doi.org/10.1016/j.colsurfb.2003.12.009

[19] Horniak, L., Ebringer, L. and Balgavý, P. (1990) Interaction of Bactericidal Bis-Ammonium Salts with Model and Bacterial Membranes. IUMS Congress: Bacteriology and Mycology, Osaka, 16-22 September 1990, Book of Abstracts, 171.

[20] Iwamoto, S., Otsuki, M., Sasaki, Y., Ikeda, A. and Kikuchi, J. (2004) Gemini Peptide Lipids with Ditopic Ion-Recognition Site. Preparation and Functions as an Inducer for Assembling of Liposomal Membranes. Tetrahedron, 60, 9841-9847. http://dx.doi.org/10.1016/j.tet.2004.08.072

[21] Bell, P.C., Bergsma, M., Dolbnya, I.P., Bras, W., Stuart, M.C.A., Rowan, A.E., Feiters, M.C. and Engberts, J.B.F.N. (2003) Transfection Mediated by Gemini Surfactants: Engineered Escape from the Endosomal Compartment. Journal of the American Chemical Society, 125, 1551-1558. http://dx.doi.org/10.1021/ja020707g

[22] David, S., Pérez, L. and Infante, M.R. (2002) Sequestration of Bacterial Lipopolysaccharide by Bis(Args) Gemini Compounds. Bioorganic \& Medicinal Chemistry Letters, 12, 357-360. http://dx.doi.org/10.1016/S0960-894X(01)00749-1

[23] Diz, M., Manresa, A., Pinazo, A., Erra, P. and Infante, M.R. (1994) Synthesis, Surface Active Properties and Antimicrobial Activity of New Bis Quaternary Ammonium Compounds. Journal of the Chemical Society, Perkin Transactions, 2, 1871-1876. http://dx.doi.org/10.1039/p29940001871

[24] Okazaki, K., Maeda, T., Nagamune, H., Manabe, Y. and Kourai, H. (1997) Synthesis and Antimicrobial Characteristics of 4,4'-( $\alpha, \omega$-Polymethylenedithio)bis(1-alkylpyridinium iodide)s. Chemical and Pharmaceutical Bulletin, 45, 19701974.

[25] Maeda, T., Manabe, Y., Yamamoto, M., Yoshida, M., Okazaki, K. and Nagamune, H. (1999) Synthesis and Antimicrobial Characteristics of Novel Biocides, 4,4'-(1,6-Hexamethylenedioxy dicarbonyl)bis(1-alkylpyridinium iodide)s. Chemical and Pharmaceutical Bulletin, 47, 1020-1023.

[26] Iyer, S.S., Rele, S.M., Baskaran, S. and Chaikof, E.I. (2003) Design and Synthesis of Hyaluronan-Mimetic Gemini Disaccharides. Tetrahedron, 59, 631-638. http://dx.doi.org/10.1016/S0040-4020(02)01567-3

[27] Shirai, A., Maeda, T., Nagamune, H., Matsuki, H., Kaneshina, S. and Kourai, H. (2005) Biological and Physicochemical Properties of Gemini Quaternary Ammonium Compounds in Which the Positions of a Cross-Linking Sulfur in the Spacer Differ. European Journal of Medicinal Chemistry, 40, 113-123. http://dx.doi.org/10.1016/j.ejmech.2004.09.015 
[28] Chaudier, Y., Zito, F., Barthélémy, P., Stroebel, D., Améduri, B., Popot, J.L. and Pucci, B. (2002) Synthesis and Preliminary Biochemical Assessment of Ethyl-Terminated Perfluoroalkylamine Oxide Surfactants. Bioorganic \& Medicinal Chemistry Letters, 12, 1587-1590. http://dx.doi.org/10.1016/S0960-894X(02)00242-1

[29] Massi, L., Guittard, F., Géribaldi, S., Levy, R. and Duccini, Y. (2003) Antimicrobial Properties of Highly Fluorinated Bis-Ammonium Salts. International Journal of Antimicrobial Agents, 21, 20-26. http://dx.doi.org/10.1016/S0924-8579(02)00271-6

[30] Massi, L., Guittard, F. and Géribaldi, S. (2000) Application en Tant que Biocides des Composés QUATERFLUO ${ }^{\circledR}$. MC Patent No. 2452.

[31] Tewari, N., Tiwari, W.K., Tripathi, R.P., Chaturvedi, V., Srivastava, A., Srivastava, R., Shukla, P.K., Chaturvedi, A.K., Gaikwad, A., Sinha, A. and Srivastava, B.S. (2004) Synthesis of Galactopyranosyl Amino Alcohols as New Class of Antitubercular and Antifungal Agents. Bioorganic Medicinal Chemistry Letters, 14, 329-332. http://dx.doi.org/10.1016/j.bmcl.2003.11.020

[32] Botana López, L., Landoni, M.F. and Martin Jiménez, T. (2002) Farmacología Terapéutica Veterinaria. McGraw-Hill International, Madrid.

[33] European Commission (2005) Institute for Health and Consumer Protection. European Chemicals Bureau I-21020 Ispra (VA) Italy. Summary Risk Assessment Report. ALKANES, C14-17, CHLORO (MCCP) Part I-Environment. CAS No. 85535-85-9. EINECS No. 287-477-0 SUMMARY RISK ASSESSMENT REPORT. Final Report, The United Kingdom Rapporteur.

[34] Meneses, E.S., Arguelho, M.L.P. and Alves, J.P.H. (2005) Electroreduction of the Antifouling Agent TCMTB and Its Electroanalytical Determination in Tannery Wastewaters. Talanta, 67, 682-685. http://dx.doi.org/10.1016/j.talanta.2005.01.058

[35] Vogel, A.I. (1989) Vogel’s Textbook of Practical Organic Chemistry. 5th Edition, John Wiley \& Sons, Inc., New York.

[36] Chlebicki, J., Węgrzyńska, J., Maliszewska, I. and Oświęcimska, M. (2005) Preparation, Surface-Active Properties, and Antimicrobial Activities of Bis-Quaternary Ammonium Salts from Amines and Epichlorhidrin. Journal of Surfactants and Detergents, 8, 227-232. http://dx.doi.org/10.1007/s11743-005-0350-6

[37] National Committee for Clinical Laboratory Standards (2002) Reference Method for Broth Dilution Antifungal Susceptibility Testing of Yeasts. M27-A2. NCCLS, Wayne.

[38] National Committee for Clinical Laboratory Standards (2002) Reference Method for Broth Dilution Antifungal Susceptibility Testing of Filamentous Fungi. M38-A. NCCLS, Wayne.

[39] Sager, R. and Granik, S. (1953) Nutritional Studies with Chlamydomonas Reinhardti. Annals of the New York Academy of Sciences, 56, 831-838. http://dx.doi.org/10.1111/j.1749-6632.1953.tb30261.x

[40] USEPA (2002) Short Term Methods for Estimating the Chronic Toxicity of Effluents and Receiving Waters to Fresh Water Organism. 4th Edition, EPA-821-R-02-013, Washington DC.

[41] Reno, U., Gutierrez, M.F., Regaldo, L. and Gagneten, A.M. (2014) The Impact of Eskoba ${ }^{\circledR}$, a Glyphosate Formulation, on the Freshwater Plankton Community. Water Environment Research, 86, 2294-2300. http://dx.doi.org/10.2175/106143014X13896437493580

[42] American Public Health Association (APHA) (1998) Standard Methods for the Examination of Water and Wastewater. 21st Edition, APHA, Ap 8010G, Washington DC, 8-20, 8-23.

[43] Ronco, A., Díaz Báez, M.C. and Pica Granado, Y. (2003) Ensayos Toxicológicos y Métodos de Evaluación de Calidad de Aguas. Estarandización, Intecalibración, Resultados y Aplicaciones. 47-52.

[44] US Environmental Protection Agency (2002) Methods for Measuring the Acute Toxicity of Effluents and Receiving Waters to Freshwater and Marine Organisms. EPA-821/R-02-012, Washington DC.

[45] Finney, D.J. (1971) Probit Analysis. Cambridge University Press, Cambridge, 333.

[46] Lofrano, G., Belgiorno, V., Gallo, M., Raimo, A. and Meric, S. (2006) Toxicity Reduction in Leather Tanning Wastewater by Improved Coagulation Flocculation Process. Global NEST Journal, 8, 151-158.

[47] Terra, N.R., Feiden, I.R., Lucheta, F., Gonçalves, S.P. and Gularte, J.S. (2010) Bioassay Using Daphnia magna Straus, 1820 to Evaluate the Sediment of Caí River (Rio Grande do Sul, Brasil). Acta Limnologica Brasiliensia, 22, 442-454. http://dx.doi.org/10.4322/actalb.2011.008

[48] Guilhermino, L., Diamantino, T., Silva, M.C. and Soares, A.M.V.M. (2000) Acute Toxicity Test with Daphnia magna: An Alternative to Mammals in the Prescreening of Chemical Toxicity. Ecotoxicology and Environmental Safety, 46, 357-362. http://dx.doi.org/10.1006/eesa.2000.1916

[49] Machuca, L.M., Lurá, M.C. and Murguía, M.C. (2011) Moléculas anfipáticas de la familia gemini. Argentina Patente Acta No. P20130103027. 